\title{
The Effect of Two Strains of LAB ( P.acidilactaci and L. lactis) In Laboratory Rats.
}

\author{
Maha M. Bikheet ${ }^{1}$, Magda E. Mahmoud ${ }^{2}$, Hanaa M. Hassan ${ }^{2 *}$ and Eman E. Yassien ${ }^{2}$. \\ ${ }^{1}$ Department of Dairy Science, Faculty of Agriculture, Minia University, El-Minia, Egypt ${ }^{2}$ Department of \\ Agricultural Chemistry, Faculty of Agriculture, Minia University, El-Minia, Egypt. \\ *Corresponding author' hanaa_hassan@mu.edu.eg (Hanaa M. Hassan)
}

Received on: 24-4-2021

Accepted on: 21-5-2021

\begin{abstract}
The purpose of this study was to evaluate the impacts of two Lactic Acid Bacteria strains (LAB) Pediococcus acidilactici (P. acidilactici) and Lactococcus Lactis (L. Lactis)) is olated fromfermented dairy products. In this study, 24 female rats were divided into three groups (8 rats per each group): (1) untreated group, (2)P. acidilactici group: rats fed orally with 108 CFU /ml skim milk, (3) L. Lactis group: rats fed orally with 108 CFU /ml skim milk for 6 weeks. Bodyweight gain, daily feed intake, relative weight org ans, hematological parameters, ALT, AST, protein, albumin, globulin, urea, creatinine, and histopathological examinations of liver and kidney were determined at the end of the experiment. Results: In this analysis, statistical significance was found for certain parameters e.g. organ weights, hematology, and clinical chemistry; none of these improvements were expected due to the treatment since the changes remained close to controls, also, his tological studies of the liver and kidney observed no and mild morphology changes in the liver or kidney. The currentstudy indicates that administration of P. acidilactici and L. Lactis strains of LAB didn't harm laboratory rats and safe for animal or human consumption.
\end{abstract}

KEYWORDS: LAB, P.acidilactaci, L. lactis, Hematological parameters, Histological studies

\section{INTRODUCTION}

Due to their long history of use, many strains of lactic acid bacteria (LAB) are commonly considered stable and their status is widely accepted as safe (Donohue, 2006). Probiotics are 'live' microbes that provide their hosts with essential health benefits (Dicks and Botes, 2010 and Hardy et al., 2013). Protection features must be addressed in addition to show ing the effectiveness of probiotics in improving human health (Donohue, 2006 and Salminen et al., 1998)

As probiotics, several bacterial species can be used, especially Lactobacillus, Bifidobacterium, Pediococcus, Lactococcus, and Leuconostoc species, although it is believed that Lactobacillus casei, Lactobacillus acidophilus and Bifidobacterium species are the most highly important species. These bacteria are part of the gastrointestinal microflora and are particularly useful for milk product digestion (Gareau et al., 2010 and Ashraf and Shah, 2014). Several clinical studies have confirmed that the daily ingestion of probiotics or their associated products, especially Lactobacillus and Bifidobacterium, dramatically enhances human health through several consequences, including vitamin $\mathrm{K}$ biosynthesis (Bentley and Meganathan, 1982), indigestible dietary fibers metabolic fermentation (Nilsson et al., 2008), competition with pathogenic microbes for mucosal epithelial cell-binding sites (Candela et al.,
2008), and modulation, regulation, and enhancement of the host immune system answer (Leroy and De Vuyst, 2004). The medicinal impact of LAB used of different fermented foods on human health has been enhanced and their use has contributed to increases in liver disease, allergies, asthma, cancer, blood cholesterol, and hyperlipidemia (Parvez et al., 2006 and Tsai et al., 2014). Rackayová et al. (2021) used behavioral experiments and ultra-high-field in vivo $1 \mathrm{H}$ MRS to see whether a multistrain probiotic mixture had a beneficial effect on behavior and neurometabolic improvements in rats after long-term treatment.. This probiotic formulation had also increased gut Bifidobacteria and attenuated changes in locomotor activity and neurometabolic profile in rats when given prophylactically.

Lactococcus lactis (L. lactis) belongs to the LAB group and is a Gram-positive bacterium. Lactic acid is typically the primary fermentation product, and glycolysis is the main energy source, L. Lactis is mostly recognized for its immense significance in the dairy industry, where this bacterium inoculates more than 100 million tonnes of milk each year for the processing of different fermented dairy products Teuber, (1995). In addition, the many years of safe use have created L. Lactis is also a preferred candidate for other significant uses, such as as a delivery vehicle for human vaccines and therapeutic peptides and as a development tool for various 
compounds. (Hugenholtz et al., 2000 and Solem et al., 2013).

The effects of oral administration of two LAB strains (P.acidilactaci and L. lactis) on health, development, hematology, daily blood chemistry in rats, and histological analysis of the liver and kidneys were investigated in this study.

\section{MATERIALS AND METHODS}

\subsection{Preparation of LAB strains:}

Isolation of $P$. acidilactis and L. lactis ssp lactis from fermented dairy products (laban zeer, laban rayeb and karish cheese) was used to create LAB strains.

Biochemical analysis and the API process were used to identify the strains. These were grown for 72 hours at $37^{\circ} \mathrm{C}$ in MRS broth for rods and M17 broth for cocci isolated (Bikheet et. al., 2015). To feed the rats, $1 \mathrm{ml}$ of each inoculation was combined with a separate aliquot of $10 \mathrm{ml}$ skim milk $(108 \mathrm{CFU} / \mathrm{mL}$ skim milk) (Zagato et al., 2014).

\subsection{Animals and Experimental Design:}

In the biological laboratory of the Chemistry Department, Faculty of Agriculture, Minia University, twenty-four Sprague-Dawley female rats $(180 \pm 5 \mathrm{~g})$ were housed. Rats were acclimatized for one week to the laboratory conditions. They were housed in special healthy plastic cages and held for water and normal diet ad libitum. The experiments were performed according to the animal care and use standards of the Institutional Animal Ethics Committee, Minia University, Egypt. The rats were assigned randomly to 3 classes on day zero (8 females per group). The control group 1 was fed on a regular chow diet and each rat was given $1 \mathrm{ml}$ of oral milk with LAB for 6 weeks. Group 2 administered $1 \mathrm{ml}$ of oral skim milk with $\mathrm{P}$. acidilactis daily to each rat for 6 weeks. Group 3 Each rat got an oral $1 \mathrm{ml}$ dose of skim milk with $\mathrm{L}$. Lactis for 6 weeks a day. Bodyweight was recorded at the beginning and throughout the experimental period. At the end of this experiment (6 weeks), blood samples were taken from the retro-orbital plexus of all rats in each group after anesthetization. All blood samples were centrifuged at $3000 \mathrm{rpm}$ for 15 minutes. The serum samples collected were kept at $-20^{\circ} \mathrm{C}$ until they were used for biochemical analysis. Animals were dissected as quickly as possible, and liver, kidney, lung, heart and brain were removed, washed in ice-cold saline, and wiped away.

\subsection{Hematological parameters:}

Blood samples were taken into tubes containing 10\% EDTA and labeled to indicate the treatment groups as well as the research intervals. Red blood cells (RBCs) and white blood cells (WBCs) were counted according to Dacie and Lew is (1984), while hemoglobin ( $\mathrm{Hb})$ was measured according to VanKampen and Zijlstra (1961). Centrifuging blood in heparinized microhematocrit tubes (capillary tubes $1 \mathrm{~mm}$ internal diameter and 7.5 $\mathrm{cm}$ length) for 5 minutes at 15,000 r.p.m. was used to assess hematocrit (HCT percent) or packed cell volume (PCV) (Dacie and Lew is, 1991). According to Schalm et al. (1975), the percentage of each form of total leucocyte population concerning the total count of WBCs was calculated.

\subsection{Clinical chemistry analysis:}

AST, ALT, total protein, albumin, blood urea nitrogen (BUN), creatinine as renal functions, and globulin were performed using commercially available kits from Bio- Diagnostic Co., Egypt.

\subsection{Histopathological studies:}

Small sections of the kidneys and liver of each control animal and treated groups were fixed for twenty-four hours in a 10\% formal saline solution. Then, samples were washed (for dehydration) with water and serial dilutions of absolute ethyl alcohol. Paraffin bees wax tissue blocks were prepared for sectioning at a thickness of 4 microns by sliding microtome after routine processing. For histopathological analysis using a light microscope, the tissue parts obtained were collected on glass slides, deparaffinized, and stained by hematoxylin and eosin stains (Banchroft et al., 1996).

\subsection{Statistical analysis:}

The mean standard error (SE) of eight measurements was used to calculate the experimental effects. ANOVA methods were used to conduct the study of variance. GraphPad Prism ${ }^{\circledR}$ was used for statistical calculations by GraphPad Software, San Diego, CA, USA (Motulsky, 1999).

\section{RESULTS AND DISCUSSION}

\subsection{Changes in body weight and consumption of food:}

All animals did not show abnormal physical, behavioral changes or unexpected deaths throughout the experiment. Data in Table (1) show s a significant elevation in body weight gain and feed efficiency ratio of about $29 \%$ and $24.3 \%$, respectively at rats received L.lactis. Although P.acidilactaci increase these parameters but not significant compared with control. 
Maha M. Bikheet et al., 2021

Table 1. Effect of P.acidilactaci and L. lactis on body weight gain and Feed intake of rat.

\begin{tabular}{lllcc}
\hline Groups & Final weight $(\mathbf{g})$ & $\begin{array}{l}\text { Bodyweight } \\
(\mathbf{g})\end{array}$ & $\begin{array}{c}\text { gain Daily } \\
\text { intake }(\mathrm{g})\end{array}$ & $\begin{array}{c}\text { feed FER } \\
(\boldsymbol{\%})\end{array}$ \\
\hline Control & $230.0 \pm 0.4$ & $54.0 \pm 0.6$ & 14.0 & $10.71 \pm 0.6$ \\
$\boldsymbol{P}$.acidilactaci & $238.0 \pm 2.6$ & $58.0 \pm 1.0$ & 14.5 & $11.73 \pm 0.2$ \\
L. lactis & $254.7 \pm 6.8^{\mathrm{a}}$ & $69.7 \pm 3.9^{\mathrm{a}}$ & 15.0 & $13.30 \pm 0.7^{\mathrm{a}}$ \\
\hline
\end{tabular}

.Data represent the mean \pm SE of observations from 8 rats. ${ }^{a}$ significant di from the control group at $\mathrm{P}<0.05$. $\mathrm{FER}=$ Feed Efficiency Ratio

The result was in the same line with Zhao et al (2020) which reported that the weight gain of rats treated with a high dose of Lactic acid bacteria (L. plantarum ATCC $8014(1 \times 109 \mathrm{CFU} / \mathrm{ml})$ was the highest - significantly higher than the weight gain of the control group of rats.

Moreover, the ability of the probiotic to utilize additional nutrients present in milk such as calcium, vitamins, carbohydrates, and proteins led to the proliferation of a greater number of $\mathrm{LAB}$ in the bodies of LAB treated animals in milk (Gasmalla et al., 2013).

In addition, the $\mathrm{LAB}$ and prebiotics effects on cholesterol metabolism (Mandal et al., 2009), While LAB alone significantly increases hypocholesterolemic in vivo (Bukowska et al., 1998 and Xie et al., 2011). Liu et al. (2019) showed that some LAB strains (Lactococcus lactis) can be used to manufacture long-chain vitamin K2efficientlyand developing the processes of vitami $\mathrm{n} \mathrm{K} 2$ biotechnological production

\subsection{Changes in relative weight organs:}

The results from Table 2 show that no major variations in relative organs weight were found (liver, kidney, heart) between two strains and the control, except for lung decrease and brain increase in P.acidilactaci group. This indicated that the $L$. lactis did not cause any adverse effects on many organs.

Table 2. Effect of P.acidilactaci and $L$. lactis on relative weight of organs:

\begin{tabular}{llllll}
\hline Group & Liver & Kidney & Heart & lung & Brain \\
\hline Control & $3.7 \pm 0.1$ & $0.62 \pm 0.06$ & $0.39 \pm 0.0$ & $0.82 \pm 0.07$ & $0.68 \pm 0.006$ \\
P.acidilactaci & $3.7 \pm 0.03$ & $0.63 \pm 0.02$ & $0.36 \pm 0.003$ & $0.67 \pm 0.013$ & $0.76 \pm 0.009^{\mathrm{a}}$ \\
L. lactis & $3.8 \pm 0.06$ & $0.67 \pm 0.02$ & $0.34 \pm 0.023$ & $0.76 \pm 0.04$ & $0.73 \pm 0.03$ \\
\hline
\end{tabular}

.Data is presented as means $\pm \mathrm{SE}$ of observations from 8 rats. ${ }^{a}$ (significantly different from the control group at $\mathrm{P}<$ 0.05 .

Several scientific studies have indicated that daily intake of probiotics, especially Lactobacillus a nd Bifidobacterium, dramatically improves human $\mathrm{h}$ ealth through a variety of effects, including vitamin K biosynthesis (Bentley and Meganathan, 1982).

The influence on the liver of feeding separate doses of mixed LAB strains, kidney, and spleen are measured by Tian et al., (2017) and Shokryazdan et al., (2016), and the organ to body ratio is determined. In the different dose classes and there were no major variations in the relative heart, kidney, testicle, or ovary weight of the rats.

Tsai et al., (2014) proved that rats fed on strains of LAB had not significant differences in the weight of the major organs, as well as the rate of daily food and water intake was similar to the control group. In this research, histopathological analyses of the organs which did not show any defects or histopathological changes in the organs confirmed our findings.

\subsection{Haematological Parameters:}

The hematological parameters such as RBCs, WBCs, Hct, MCV, and $\mathrm{MCH}$ were not signific antly changed in rats received L. lactis $s p$ lactis. However, a significant increase in these parameters was noticed in rats treated with $P$. acidilactaci (Table 3). Oral administration of $L$. lactis did not cause any significant effect on differential leucocytes to count in the female albino rat. Whereas, P.acidilactaci caused a significant increase in these parameters comparing control in the same Table.

Szabo et al., (2011) and Tsai et al., (2014) found that treatment with LAB strains had a statistical significance on parameters of hematology, none of these improvements are hypothesized to be attributable to the treatment as the changes continued in the historical controls. Also, hematological parameters were in the normal physiological range when mice fed LAB strains at different doses (Tian et al., 2017).

\subsection{Clinical chemistry analysis:}

Serum hepatic markers (ALT, AST) and concentration of serum proteins, Albumin, Globulin, urea, and creatinine results are presented in Table 4. At the terminal sampling time, clinical chemistry values for the rats treated with P.acidilactaci and $L$. 
Table 3. Haematological findings in rats that were treated orally with P.acidilactaci, L. lactis for 6 weeks.

\begin{tabular}{|c|c|c|c|}
\hline$\overbrace{\text { Grou }}^{\text {Parameters }}$ & Control & P.acidilactaci & L. lactis \\
\hline RBCs (Cell/ $/ \mu \mathrm{L})$ & $7.14 \pm 0.09$ & $7.55 \pm 0.05^{\mathrm{a}}$ & $7.43 \pm 0.08$ \\
\hline WBCs $\left(10^{3} / \mathrm{mm}^{2}\right)$ & $10.13 \pm 2.3$ & $15.60 \pm 0.5^{\mathrm{a}}$ & $10.97 \pm 0.23$ \\
\hline Het (\%) & $50.5 \pm 0.2$ & $53.3 \pm 0.4^{\mathrm{a}}$ & $50.6 \pm 0.8$ \\
\hline $\mathrm{Hgb}(\mathrm{g} / \mathrm{dL})$ & $15.43 \pm 0.3$ & $16.17 \pm 0.1$ & $15.33 \pm 0.2$ \\
\hline MCV (FL/cell) & $70 \pm 0.3$ & $71 \pm 0.7^{\mathrm{a}}$ & $70 \pm 0.7$ \\
\hline MCH (Pg/cell) & $20.8 \pm 0.4$ & $22.20 \pm 0.2^{\mathrm{a}}$ & $20.63 \pm 0.1$ \\
\hline Neut (\%) & $28 \pm 0.6$ & $37 \pm 0.3^{\mathrm{a}}$ & $28.67 \pm 0.3$ \\
\hline $\operatorname{Lym}(\%)$ & $65 \pm 0.5$ & $52 \pm 0.5^{\mathrm{a}}$ & $66 \pm 0.5$ \\
\hline $\operatorname{Mon}(\%)$ & $3 \pm 0.6$ & $5.7 \pm 0.7^{\mathrm{a}}$ & $3.3 \pm 0.3$ \\
\hline $\operatorname{Eosi}(\%)$ & $3.0 \pm 0.5$ & $2.0 \pm 0.3$ & $3.0 \pm 0.3$ \\
\hline $\operatorname{Baso}(\%)$ & 0 & 0 & 0 \\
\hline
\end{tabular}

Data are presented as means \pm SE of observations from 8 rats. ${ }^{a}$ (significantly different fromcontrol group at $\mathrm{P}<0.05 .{ }^{\mathrm{b}}$ significantly different from $\mathrm{P}$.acidilactaci group at $\mathrm{P}<0.05$

Table 4. Blood chemistry in rats that were treated orally with P.acidilactaci, L. lactis for 6 weeks.

\begin{tabular}{llll}
\hline \multicolumn{1}{c}{ Parameters } & Control & P.acidilactaci & L. lactis \\
\hline ALT (U/L) & $24 \pm 0.6$ & $25.33 \pm 1.2$ & $22 \pm 0.6^{\mathrm{b}}$ \\
AST (U/L) & $32 \pm 0.6$ & $36 \pm 0.6$ & $29 \pm 0.6$ \\
Proteins & $8.55 \pm 0.5$ & $8.05 \pm 0.4$ & $9.02 \pm 0.1$ \\
Albumin & $2.58 \pm 0.3$ & $1.67 \pm 0.02^{\mathrm{a}}$ & $2.90 \pm 0.04$ \\
Globulin & $5.97 \pm 0.046$ & $6.37 \pm 0.41$ & $6.12 \pm 0.029$ \\
Albumin/Globulin & 0.43 & 0.26 & 0.47 \\
Urea & $9.9 \pm 0.6$ & $11.3 \pm 0.8^{\mathrm{a}}$ & $9.0 \pm 0.4$ \\
Creatinine & $0.9 \pm 0.01$ & $1.3 \pm 0.1^{\mathrm{a}}$ & $1.0 \pm 0.01$ \\
\hline
\end{tabular}

Data are presented as means \pm SE of observations from 8 rats. ${ }^{a}$ (significantly different from the control group at $\mathrm{P}<$ 0.05 . ${ }^{\mathrm{b}}$ significantly different from P.acidilactaci group at $\mathrm{P}<0.05$

lactis for the control group was noticed. Statistically significant variations in the serum activity of ALT, AST, and concentration of protein and globulin were obtained, while significant increases in urea and creatinine in P.acidilactaci group. Rats of L. lactis group also, had no variations in AST, protein, albumin, globulin, urea, and creatinine. However, a significant decreases in ALT comparing with P.acidilactaci group were observed.

Moon et al., (2014) showed that rats treated with P. acidilactaci had ALT and AST closer to the control group, and lower than the high-fat diet group. No significant differences were also observed in serum albumin, urea nitrogen, total protein in a group treated with LAB strains (Tian et al., 2017). LAB strains have shown that they do not cause oral toxicity in animals (Jones et al., 2012). Suzuki et al., (2020) are ingesting L. Lactis significantly improved the condition of atopic dermatitis.

\subsection{Histopathological Examinations:}

The effects of P. acidilactaci and L.lactis spp lactis on the rats were evaluated by histological studies of the liver and kidney observed mild to moderate and no changes in the liver or kidney morphology resulting from the 6 weeks treatment with the test strains in vivo (Figs.1 and 2).

Tsai et al., (2014) and Shokryazdan et al. (2016) proved no macroscopic changes in the morphology of the liver and kidney in animals treated with the test strains of $\mathrm{LAB}$.

\section{CONCLUSION}

P. acidilactaci and L. Lactis ssp lactis isolated from fermented dairy products (laban zeer, laban rayeb, and Karish cheese) were found to be healthy at a dose of $108 \mathrm{CFU} / \mathrm{ml}$ skim milk for 6 weeks of care in this study. Both strains were well tolerated, with no adverse effects observed on development, feed consumption. There were no macroscopic improvements or noticeable variations in the relative weights and morphology of major organs. In conclusion, LAB strains ( $\mathrm{P}$. acidilactaci and L. lactis ssp lactis) are non-pathogenic and healthy to eat by humans and animals. 
Histopathological liver:
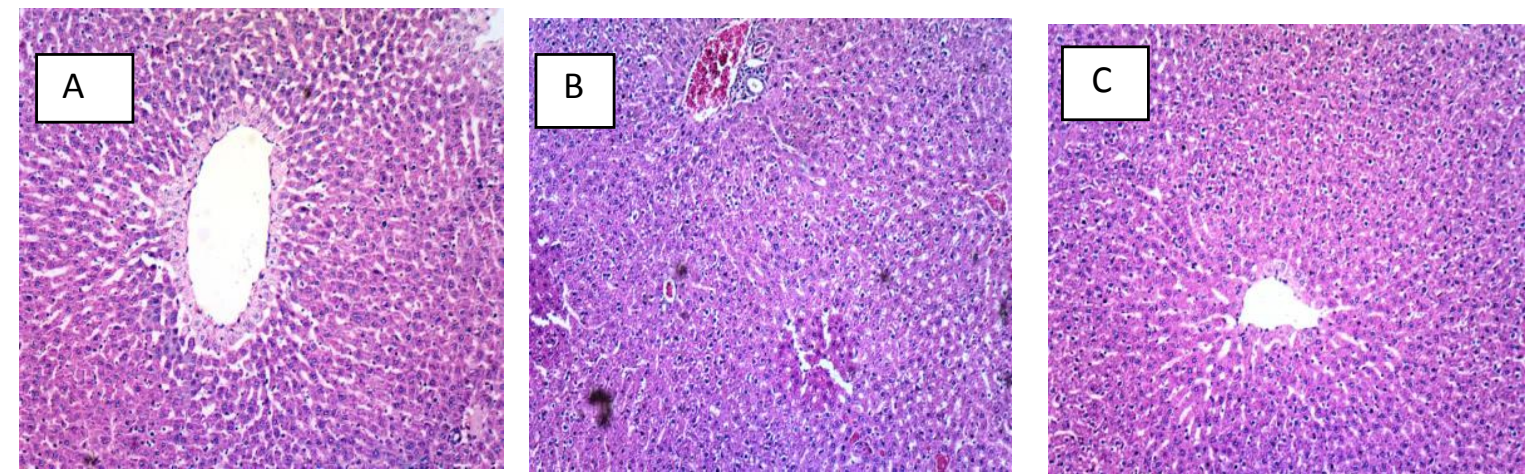

Fig 1. photomicroscograph sections of liver group of control (A), P.acidilactaci (B) and L. lactis ssp lactis $(\mathrm{C})(\mathrm{H} \& \mathrm{E}$, scale bar $=200 \mu \mathrm{m})$.

Table 5. Histopathological notes on liver tissue of rats treated with P. acidilactaci (B) and L. lactis ssp $\operatorname{lactis}(\mathbf{C})$.

\begin{tabular}{llll}
\hline & control & P. acidilactaci $(\mathbf{B})$ & L. lactis ssp lactis $(\mathbf{C})$ \\
\hline Loss architecture & - & - & - \\
Congested veine & - & + & - \\
Hepatocyte damage & - & + & + \\
\hline
\end{tabular}

(-) no, (+) mild histopathological change

Kidney Histopathological:
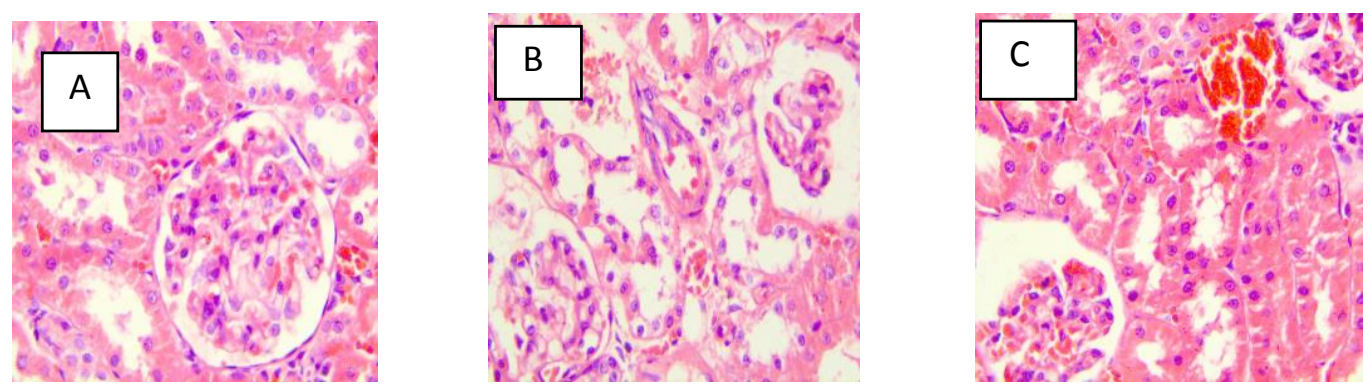

Fig 2. photomicroscograph sections of kidney group of control (A), P.acidilactaci (B) and L. lactis ssp lactis $(\mathrm{C})$. (H\&E, scale bar $=50 \mu \mathrm{m})$.

Table 6. Histopathological notes on kidney tissue of rats treated with $P$. acidilactaci $(B)$ and $L$. lactis ssp lactis $(\mathbf{C})$

\begin{tabular}{llll}
\hline & Control & P.acidilactaci $($ B) & L.lactis ssp lactis $(\mathbf{C})$ \\
\hline Glomerular structure damage & - & + & + \\
Congested blood vessel & - & + & ++ \\
Dilated tubules \& damage epithelium & - & + & - \\
\hline
\end{tabular}

(-) no, (+) mild, (++) moderate hispathological changes

\section{REFERENCES}

Ashraf R, and Shah N P (2014) Immune system stimulation by probiotic microorganisms. Crit Rev Food Sci Nutr., 54: 938-56.

Banchroft J D, Stevens A and Turner D R (1996) Theory and practice of histological techniques. Fourth Ed. Churchil Livingstone, New York, London, San Francisco, Tokyo, 10:766.

Bentley R and Meganathan R (1982) Biosynthes is of vitamin $\mathrm{K}$ (menaquinone) in bacteria. Microbiol Rev, 46: 241-80.

Bikheet M M, Darwish A M, Hassanein K A and Shalaby S I (2015) Lactic acid bacteria with potential to eliminate fungal spoilage in cheeses) proceeding The 2nd . Minia International Conference " Agriculture and Irrigation in Nile Basin Countries" 32-25 march, Minia, Egypt (312317).

Bukowska H, Pieczul-Mroz J, Jastrzebska M, Chelstowski K and Naruszewicz M (1998) Decrease in fibrinogen and ldl-cholesterol levels upon supplementation of diet with lactobacillus plantarum in subjects with moderately elevated cholesterol. Atherosclerosis., 137: 437-438.

Candela M, Perna F, Carnevali P, Vitali B, Ciati R, Gionchetti P, Rizzello F, Campieri M 
and Brigidi $P$ (2008). Interaction of probiotic Lactobacillus and Bifidobacterium strains with human intestinal epithelial cells: adhesion properties, competition against enteropathogens and modulation of IL-8 production. Int J Food Microbiol, 125: 28692.

Dacie S J V and Lewis S M (1984) Practical haematology. 6th Edition, Churchill Livingstone, 2227.

Dacie J V and Lewis S M (1991) Practical Haematology. Churchill Livingstone. Edinburgh. Seventh edition. 521-534.

Dicks L M and Botes $M$ (2010) Probiotic lactic acid bacteria in the gastro-intestinal tract: Health benefits, safety and mode of action. Benef. Microbes, 1: 11-29.

Donohue C D (2006) "Safety of probiotics," Asia Pacific Journal of Clinical Nutrition, vol. 15, no. 4, pp. 563-569.

Gareau M G, Sherman $M P$ and Walker A W (2010) Probiotics and the gut microbiota in intestinal health and disease. Nat Rev Gastroenterol Hepatol, 7: 503-14.

Gasmalla M, Khadir K, Musa A, Aboshora W and Zhao W (2013) Evaluation of some physicochemical parameters of three commercial milk products. Pak. J. Food Sci., 23(2):62-65.

Hardy H, Harris J, Lyon E, Beal J and Foey D A (2013) Probiotics, prebiotics and immunomodulation of gut mucosal defences: homeostasis and immunopathology. Nutrients, 5: 1869-912.

Hugenholtz J, Kleerebezem M, Starrenburg M, Delcour J, De Vos $W$ and Hols $P$ (2000). Lactococcus lactis as a cell factory for high-level diacetyl production. Appl. Environ. Microbiol. 66: 4112-4114.

Jones M L, Martoni C J, Tamber S, Parent M and Prakash S (2012) "Evaluation of safety and tolerance of microencapsulated Lactobacillus reuteri NCIMB 30242 in a yogurt formulation: a randomized, placebo-controlled, double-blind study," Food and Chemical Toxicology, vol. 50, no. 6, pp. 2216-2223

Leroy F and De Vuyst L (2004) Lactic acid bacteria as functional starter cultures for the food fermentation industry. Trends Food Sci. Technol. 15: $67-78$.

Liu Y, Bennekom V O E, Zhang Y, Abee T and Smid J $\quad \mathbf{E}$ (2019) Long-chain vitamin $\mathrm{K} 2$ production in Lactococcus lactis is influenced by temperature, carbon source, aeration and mode of energy metabolism. Microb Cell Fact, 18:129

Mandal V, Sen S and Mandal N (2009) Effect of prebiotics on bacteriocin production and cholesterol lowering activity of Pediococcus acidilactici lab 5. World J. Microbiol. Biotechnol., 25:1837-1847.

Moon Y J, Baik S H and Cha Y S (2014) LipidLowering Effects of Pediococcus acidilactici M76 Isolated from Korean Traditional Makgeolli in High Fat Diet-Induced Obese Mice. Nutrients , 6, 10161028.

Motulsky H J (1999) Analyzing Data with GraphPad Prism, GraphPad Software Inc., San Diego CA, www.graphpad.com.

Nilsson C A, Ostman E, Holst J J and Bjorck E I (2008) Including indigestible carbohydrates in the evening meal of healthy subjects improves glucose tolerance, lowers inflammatory markers, and increases satiety after a subsequent standardized breakfast. J Nutr, 138: 732-9.

Parvez S, Malik K, Ah Kang S and Kim H Y (2006) Probiotics and their fermented food products are beneficial for health. J. Appl. Microbiol. 100: 1171-1185.

Rackayová V., Flatt E., Braissant2 O., Grosse J., Capobianco D., Mastromarino P., McMillin M., DeMorrow S.,McLin V. A. and Cudalbu C. (2021) Probiotics improve the neurometabolic profile of rats with chronic cholestatic liver disease. Scientific Reports, 11:2269

Salminena S, Wrightb A, Morellic L, Marteaud P, Brassarte D, Vosf MW, Fondéng, R, Saxelinh M, Collinsi K, Mogensen G, Birkeland $\mathrm{S}$ and Mattila-Sandholm, T (1998) "Demonstration of safety of probiotics-a review," International Journal of Food Microbiology, vol. 44, no. 1-2, pp. 93-106.

Schalm O W, jain N C and Carroll E J (1975) Veterinary Haematology. 3rded. Lea and Febiger, Philadelphia, pp. 66-180.

Shokryazdan P, Jahromi F M, Liang B J, Kalavathy R, Sieo Ch $\mathrm{Ch}$ and Ho W Y (2016) Safety Assessment of Two New Lactobacillus Strains as Probiotic for Human Using a Rat Model. PLOS ONE DOI:10.1371/journal.pone.0159851.

Solem C, Dehli T and Jensen P R (2013) Rewiring Lactococcus lactis for ethanol production. Appl. Environ. Microbiol. 79: 2512-2518.

Suzuki 1 T, Nishiyama K, Kawata K, Sugimoto K, Isome M, Suzuki Sh, Nozawa R, Ichikawa Y, Watanabe Y and Suzutani T (2020) Effect of the Lactococcus Lactis 11/19-B1 Strain on Atopic Dermatitis in a Clinical Test and Mouse Model. Nutrients, 12: 763.

Szabo N J, Laurie C, Dolana G A, Burdocka T S, Satob H S, Tohru U, Satoko Y, Masamichi T and Hirofumi U, (2011) Safety evaluation of Lactobacillus pentosus strain b240. Food and Chemical Toxicology Volume 49, Issue 1, January 2011, Pages 251-258. 
Teuber M (1995) In The Genera of Lactic Acid Bacteria Vol. 2 The Lactic Acid Bacteria (eds B. J. B. Wood \& W. H. Holzapfel) Ch., 6: 173-234.

Tian Jipeng, Zhenzhen Li-, Zhu Yu , Qing Zhang and Xujiao Li (2017) Interactive effect of inoculant and dried jujube powder on the fermentation quality and nitrogen fraction of alfalfa silage. Anim. Sci. J. 88, 633-642.

Tsai Y T, Cheng PC and Pan TM (2014) Antiobesity effects of gut microbiota are associated with lactic acid bacteria. Appl. Microbiol. Biotechnol. 98: $1-10$.

Van Kampen E J, and Zijlstra W G (1961) Standardization of hemo- globinometry. II. The hemiglobincyanide method. Clin. Chim Acta.;6:53844

Xie N, Cui Y, Yin Y N, Zhao X, Yang, J.W.; Wang, Z.G.; Fu, N.; Tang, Y.; Wang, X.H.; Liu,
X.W.; Wang, Ch.- L. and Lu, F.-G. (2011). Effects of two Lactobacillus strains on lipid metabolism and intestinal microflora in rats fed a high-cholesterol diet. BMC Complement. Altern. Med., 11: 53.

Zagato E, Mileti E, Massimiliano L, Fasano F, Budelli A, Penna G (2014) Lactobacillus paracasei CBA L74 Metabolic Products and Fermented Milk for Infant Formula Have Anti-Inflammatory Activity on Dendritic Cells In Vitro and Protective Effects against Colitis and an Enteric Pathogen In Vivo. PLoS ONE 9(2): e87615.

Thao S, Zhao X, Liu Q, Jiang Y, Li Y, Feng W, Xu H and Shao1 M (2020) Protective effect of Lactobacillus plantarum ATCC8014 on acrylamideinduced oxidative damage in rats. Appl Biol Chem 63:43.

\section{تأثير سلالتين من بكتريا حض اللاكتيك P.acidilactaci و L. lactis في فئران التجارب}

$$
\begin{aligned}
& \text { مها محمود بخيت' ، ماجدة عويس محمود ‘ ، هناء محمد حسن ، إيمان الحسيني ياسين' . } \\
& \text { 'قسم علوم الألبان ، كلية الزراعة ، جامعة المنيا ، ` قسم الكيمباء الزراعية ، كلية الزراعة ، جامعة المنيا }
\end{aligned}
$$

\footnotetext{
الغرض من هذه الدراسة هو تقييم نتأثير سلالتين من بكتيريا حمض اللاكتيك Pediococcus acidilactici (P. acidilactici) و المعزولين من منتجات الألبان المخمرة ، في هذه الدراسة ، تم تقسيم ع أنثى من الجرذان. إلى ثلاث

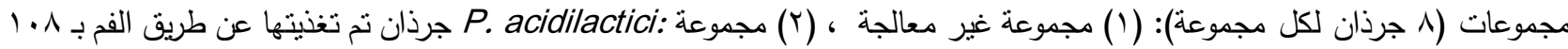

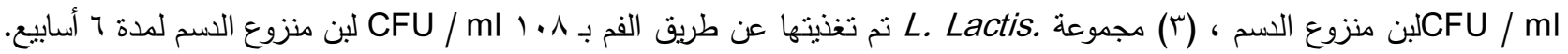

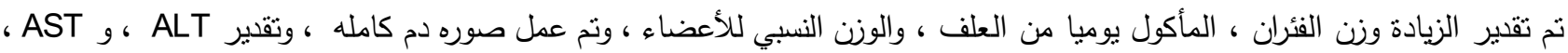
والبروتين ، والألبومين ، والجلوبيولين ، واليوريا ، والكريانتينين ، والفحص المرضي للكبد والكلى في نهاية التجربة. النتائج: في هذه التحليلات،

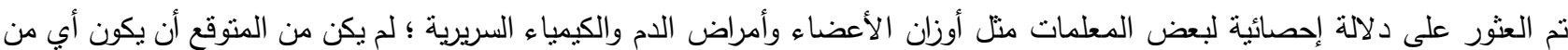

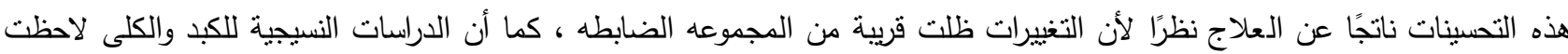

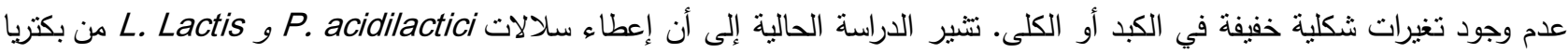
حمض اللاكتيك لم يكن له نأثير سلبي على فئران التجارب وهو آمن للاستهلاك الحيواني أو البشري. الكلمات الدالة: - LAB . ، Lactis . P.acidilactaci، تقديرات الدم ، الدراسات النسيجية.
} 